In cooperation with the U.S. Air Force, Aeronautical Systems Center, Environmental Management Directorate, Wright-Patterson Air Force Base, Ohio

\title{
Overview-Development of a Geodatabase and Conceptual Model of the Hydrogeologic Units Beneath Air Force Plant 4 and Naval Air Station- Joint Reserve Base Carswell Field, Fort Worth, Texas
}

Air Force Plant 4 (AFP4) and adjacent Naval Air Station-Joint Reserve Base Carswell Field (NAS-JRB) at Fort Worth, Tex., constitute a contractor-owned, government-operated facility that has been in operation since 1942 . Contaminants from the 3,600-acre facility, primarily volatile organic compounds (VOCs) and metals, have entered the ground-water-flow system through leakage from waste-disposal sites and from manufacturing processes.

Environmental data collected at AFP4 and NAS-JRB during 1993-2002 created the need for consolidation of the data into a comprehensive temporal and spatial geodatabase. The U.S. Geological Survey (USGS), in cooperation with the U.S. Air Force Aeronautical Systems Center Environmental Management Directorate, developed a comprehensive geodatabase of temporal and spatial environmental data associated with the hydrogeologic units beneath the facility. A three-dimensional conceptual model of the hydrogeologic units integrally linked to the geodatabase was designed concurrently.

Three hydrogeologic units-from land surface downward, the alluvial aquifer, the GoodlandWalnut confining unit, and the Paluxy aquifer-compose the subsurface of interest at AFP4 and NAS-JRB. The alluvial aquifer consists primarily of clay and silt with sand and gravel channel deposits that might be interconnected or interfingered. The Goodland-Walnut confining unit directly underlies the alluvial aquifer and consists of limestone, marl, shale, and clay. The Paluxy aquifer is composed of dense mudstone and fine- to coarse-grained sandstone.

\section{Geodatabase}

The geodatabase design uses a thematic layer approach to create layers of feature data using a geographic information system (GIS).
Using this approach, the various features are separated into relational tables in the geodatabase on the basis of how they interact and correspond to one another. These relational tables represent a collection of features and the relations between them. A base layer contains all static features, which comprise buildings, roads, surface-water bodies, and other entities that depict the surface features. A location layer contains all sampling points (historical and active) at the facility. Within this layer are 12 relational tables that encompass well-construction, lithology, water-level, and water-quality data (fig. 1). The goal is to provide accurate representations of the locations and spatial extent of the AFP4 and NAS-JRB environmental data, along with a means for conducting complex spatial analyses.
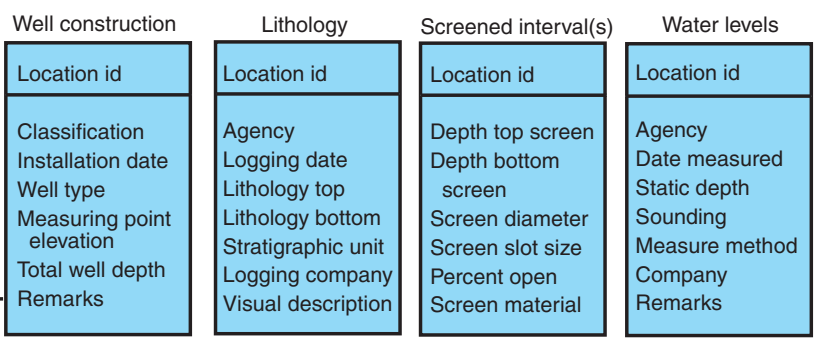
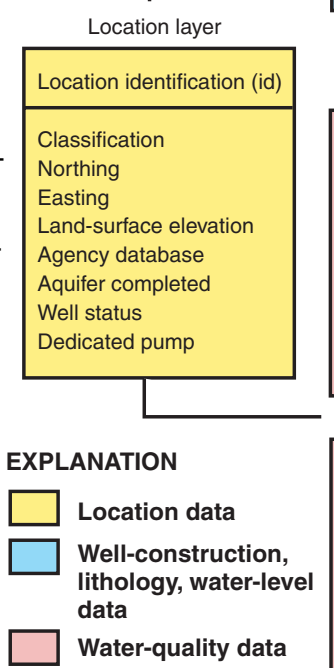

\begin{tabular}{|c|c|c|c|}
\hline \multirow{2}{*}{$\begin{array}{c}\Gamma \\
\text { Trichloroethene }\end{array}$} & \multicolumn{2}{|c|}{ Volatile organic compounds } & \multirow{2}{*}{ Tetrachloroethene } \\
\hline & Dichloroethene & Vinyl chloride & \\
\hline Location id & Location id & Location id & Location id \\
\hline Agency & Agency & Agency & Agency \\
\hline Contaminant & Contaminant & Contaminant & Contaminant \\
\hline Date measured & Date measured & Date measured & Date measured \\
\hline Matrix & Matrix & Matrix & Matrix \\
\hline Concentration & Concentration & Concentration & Concentration \\
\hline & Unit & Unit & Unit \\
\hline Detection limit & Detection limit & Detection limit & Detection limit \\
\hline Data source & Data source & Data source & Data source \\
\hline Benzene & Toluene & Ethylbenzene & Xylene \\
\hline Location id & Location id & Location id & Location id \\
\hline Agency & Agency & Agency & Agency \\
\hline Contaminant & Contaminant & Contaminant & Contaminant \\
\hline Date measured & Date measured & Date measured & Date measured \\
\hline Matrix & Matrix & Matrix & Matrix \\
\hline Concentration & Concentration & Concentration & Concentration \\
\hline Unit & Unit & Unit & Unit \\
\hline Detection limit & Detection limit & Detection limit & Detection limit \\
\hline Data source & Data source & Data source & Data source \\
\hline
\end{tabular}

Figure 1. Relational tables within location layer of geodatabase. 
The geodatabase is accessed using a GIS that integrates the spatial framework of the geodatabase and manages the environmental data. The GIS provides information to users through interactive sessions with maps and symbols on a personal computer. Thus, the geodatabase coupled with the GIS accepts queries for and retrieves specific geologic, hydrologic, and water-quality information.

\section{Conceptual Model}

The conceptual model for AFP4 and NAS-JRB comprises computer-generated three-dimensional (oblique view) block diagrams of the hydrogeologic units (fig. 2). The model provides a platform for visualization of hydrogeologic-unit sections and surfaces and for analyses involving, for example, spatial distribution of contaminants and evaluation of remediation alternatives. The model also provides a framework for future conceptualization of groundwater-flow or contamination-transport modeling.

The conceptual model is based on three structural surfaces and two thickness configurations at AFP4 and NAS-JRB. The three structural surfaces depict the altitudes of the tops of the three hydrogeologic units. The two thickness configurations are those of the alluvial aquifer and the Goodland-Walnut confining unit.

From a conceptual standpoint, identifying the hydrogeologic units and structural surfaces of the hydrogeologic units as they relate to all static and dynamic features is essential. The data used in the three-dimensional model consist of both spatial and physical information. The modeling process, in most cases, involved associating the altitude (elevation) of rocks of a given lithologic description with a particular point in three-dimensional space identified by northing, easting, and elevation coordinates.

The surface of the alluvial aquifer (top diagram at right) was created using a USGS 10-meter digital elevation model. The top of the Goodland-Walnut confining unit (middle diagram at right) was compiled from lithologic logs from existing wells, available soil-boring logs, and previous

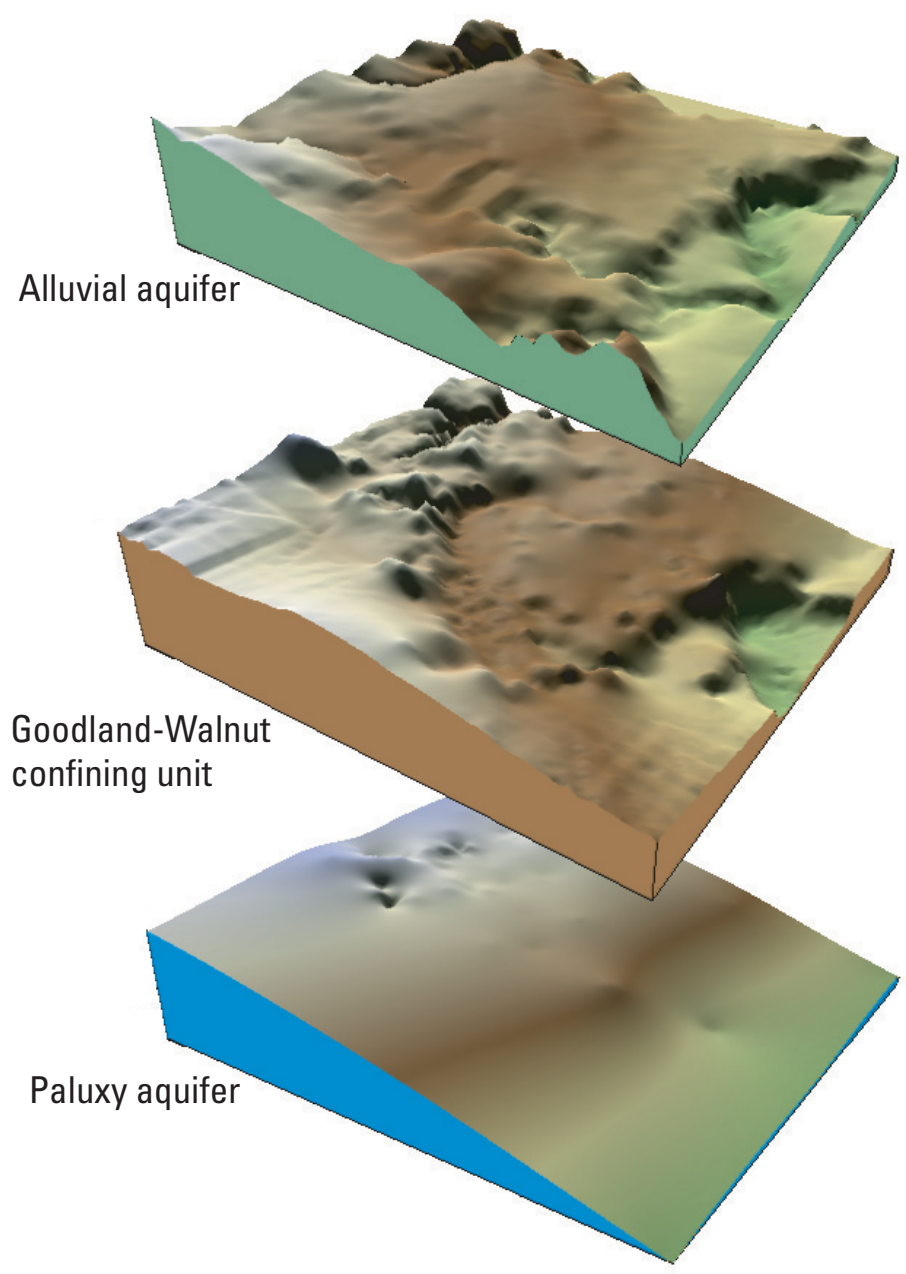

Figure 2. Block-diagram composite of hydrogeologic units (three-dimensional conceptual model), AFP4 and NAS-JRB.

studies. The top of the Paluxy aquifer (bottom diagram above) was the most challenging to depict because of a lack of altitude data for that unit throughout the study area. Data from 120 wells were obtained primarily from existing reports and used to create a map of the approximate altitude of the top of the Paluxy aquifer.

\section{- Sachin D. Shah}

\section{This fact sheet is based on the report}

Shah, S.D., 2004, Development of a geodatabase and conceptual model of the hydrogeologic units beneath Air Force Plant 4 and Naval Air Station-Joint Reserve Base Carswell Field, Fort Worth, Texas: U.S. Geological Survey Scientific Investigations Report 2004-5062, 77 p.

\section{For additional information, please contact}

District Chief

U.S. Geological Survey

8027 Exchange Dr.

Austin, TX 78754-4733

E-mail: dc_tx@usgs.gov

Phone: (512) 927-3500

FAX: (512) 927-3590

World Wide Web: http://tx.usgs.gov/ 